\title{
MARK-UP VS. INTEREST-BASED FINANCING ON GDP: AN APPLICATION OF AGENT-BASED COMPUTATIONAL MODEL
}

\author{
Diyah Putriani ${ }^{1}$, Gairuzazmi Mat Ghani ${ }^{2}$ and Mira Kartiwi ${ }^{3}$ \\ ${ }^{1}$ Department of Economics, Universitas Gadjah Mada, Indonesia, diyah.putriani@ugm.ac.id \\ ${ }^{2}$ Department of Economics, International Islamic University Malaysia, Malaysia, gairuzazm@iium.edu.my \\ 3 Department of Informatics System, International Islamic University Malaysia, Malaysia, mira@iium.edu.my
}

\begin{abstract}
This study aims to introduce the application of artificial intelligence in the area of Islamic finance by examining the dynamic changes of gross domestic product (GDP) under fully markup-based financing. The application of artificial intelligence using agent-based computational model $(\mathrm{ABM})$ is employed to conduct the simulation. The simulation result shows that the movement of GDP under markup-based financing which represents Islamic financial system has better performance compared to interestbased lending. In this regard, profit shared to depositors has positive impact on GDP which also proofs that Islamic banking system may promote sustainable economic growth and may create wealth for the whole society. This study proofs that Islamic bank essentially more stable than conventional bank and hence may fights against crisis. This study is potentially the initial work to examine the dynamic changes of economic growth under fully Islamic financial system by applying artificial intelligence concept as its methodology. Thus, this study is expected to contribute to the development of Islamic economics and finance research.
\end{abstract}

Keywords: Agent-based computational model, Interest-based lending, Markup-based financing, GDP growth.

JEL classification: C61; C63; E23; O10.

Article history:

Received : October 8, 2021

Revised : February 2, 2021

Accepted : February 19, 2021

Available online : February 28, 2021

https://doi.org/10.21098/jimf.v7i1.1345

1 The corresponding author would like to thank LPDP (Lembaga Pengelola Dana Pendidikan), Ministry of Finance, Republic of Indonesia, for the award of a research endowment. In addition, the authors would like to thank the reviewers for their instructive comments and to thank Rema Prostinaldo Yunanto for his assistantship to this project. 


\section{INTRODUCTION}

\subsection{Background}

In December 2019, the Chinese economy was shaken by COVID-19, which soon had an effect on economies worldwide. Social distancing, business closures, and even economic lockdown were some immediate policies taken by countries to fight the aggressive outbreak of the disease. These policies, however, caused fundamental problems such as a significant decrease in production and consumption, which later led to an increase in the number of job losses, as well as cash constraint issues for individual workers. Governments around the world announced economic stimulus packages to avoid their economies plunging into deeper crisis. These were in the form of interest-based loans or cash transfers and fundamentally aimed at inducing aggregate consumption. Freedman et al. (2010), however, found that such packages may cause debt accumulation and hence will have a negative impact on the economy in the long run. In addition, Cogan and Taylor (2010) showed that these packages have no material effect on economic growth. In other words, the provision of stimulus packages, particularly in the form of interestbased loans, may cause debt traps for creditors in the long run, which later could have a negative effect on the economy.

The Islamic financial system is argued to be a solution to preventing the negative impact of loans on the economy in the long term. The main feature of this system is interest-free lending. Historically, the main purpose of establishing the Islamic financial system was to remove the existence of interst rates and to promote the application of the profit-and-loss sharing (PLS) scheme as an alternative (Ahmad, 1984, 1987; Chapra, 1985; Nawab \& Naqvi, 1997; Rosly et al., 2003; Siddiqi, 1983). One of the unique features of PLS is that Islamic financial instruments are more closely related to productive activities and hence are more inclusive with regard to growth. It is thus expected that such instruments depend on and grow in tandem with real economic activities. Accordingly, the application of risk-sharing instruments is argued to be more stable in face of shocks, as Islamic financial institutions have avoided investing in the speculative financial activities which became the source of the recent financial crisis (Ahmed, 2010; Azmat et al., 2014; Nabi, 2012; Smolo \& Mirakhor, 2010; Sugema et al., 2010). As the features of PLS-based financing may reduce economic shock, it is argued that the Islamic financial system promotes economic growth (Abduh \& Omar, 2015; Abdul, 2013; Elhachemi \& Othman, 2015a; Farahani, Yasdan Gudarzi and Dastan, 2013; Imam \& Kpodar, 2015; Tabash \& Dhankar, 2014b; Wild, 2015; Zirek et al., 2016).

However, the current practice of Islamic financial institutions is to apply a markup ${ }^{2}$-based scheme, which is economically similar to interest-based lending. Only a negligible proportion of Islamic financial products follow the ideal PLS mode. For instance, out of the 189 Islamic financial institutions operating under the Islamic Financial Services Board (IFSB), total financing based on the PLS scheme (Mudharabah and Musyarakah) in the fourth quarter of 2018 was only around 5 percent. On the other hand, total financing based on the markup scheme (Murabahah contracts) on average reached more than 85 percent.

2 Markup based financing refers to all Islamic financing agreements, except qard hasan, mudharabah and musyakarah. 
This small percentage of PLS-based financing in current practice indicates that Islamic financial institutions are distancing themselves from the ideal situation. However, many empirical studies show that the current practice, as is the case with conventional bank lending, is also able to promote economic growth. At this point, a question arises: if loan packages are based on the markup scheme, would the Islamic financial system promote economic growth and be more resilient than the conventional system?

The study is divided into five sections. The first part introduces the research and includes the research gap and contribution. The second part reviews the relevant literature, while the third elucidates the selected research method. The fourth section examines the results and analysis, while the conclusion and policies recommendation are detailed in the fifth section. Finally, some ideas for future research are given in the final section.

\subsection{Objective}

In response to the problem discussed above, there is a need to simulate all stimulus package loans based on the markup scheme. Therefore, this research proposes to examine and simulate the dynamic changes in gross domestic product (GDP) under full markup-based financing. The application of artificial intelligence using a computational agent-based model $(\mathrm{ABM})$ is employed to conduct the simulation. There are two reasons for applying an ABM in this research. First, the nature of the financial system is complex, hence research needs to be conducted which involves transactions between households, firms and banks. In this regard, the growing complexity and interconnectedness of financial systems suggest that the model constructed should include collective intelligence and exhibit the emergent behaviour of agents at the macro level (El-Masri, 2015). A simulation using an $\mathrm{ABM}$ framework is able to observe the interaction of each economic agent in the economy, as well as investigating the emergence at the macro level. One such class of model that could achieve this objective is a computational agent-based model $(\mathrm{ABM})$. Many significant studies have suggested applying ABMs to cover complex interactions amongst economic agents (Arthur 1994, 1999, 2013; Arthur, Durlauf, \& Lane 1997; Oh, 2015). Therefore, it is expected that the results will show the dynamic changes in economic growth in the very long term under the Islamic financial system. Second, the application of an ABM in this research involves the use of artificial intelligence to develop the research in the area of Islamic economics and finance.

\section{LITERATURE REVIEW}

\subsection{Background Theory}

The relationship between financial development and economic growth has been a subject of discussion in theoretical and empirical studies. From a historical standpoint, over the course of decades, the systematic role of financial development has been crucial in economic development. Rousseau and Sylla (2004), using data from the nineteenth century United States, found that financial revolution leads to rapid growth of the real economy, as well as strengthening the global 
economy and military hegemony. Similar findings have been found in relation to seventeenth century Holland (de Vries and van der Woude, 1997) and eighteenth century England (North and Weingast, 1989). On the other hand, the absence of financial literature held back substantial economic growth in several developing countries, including nineteenth century Russia (Anan'ich, 1999), nineteenth century Argentina (Davis and Gallman, 2001), and early twentieth century Mexico (Haber, 1991, 1997). The main idea of these previous studies is that financial innovation is essential for economic development to take place.

Several works using an empirical approach have obtained similar results to the historical literature on the relationship between financial development and economic growth. Using the frameworks of Goldsmith (1969) and McKinnon (1973), King and Levine (1993) found that higher levels of banking system development lead to faster rates of physical capital accumulation and have a positive impact on economic growth. In addition, Benhabib and Spiegel (2000) found that the indicators of financial development are correlated with both total factor productivity growth and investment, although their results are sensitive to the inclusion of country fixed effects. This indicates that financial development indicators can be used as a proxy for broader country characteristics. Ram (1999) and Deidda and Fattouh (2001) criticized the use large cross-country panels, claiming they would lead to huge parametric heterogeneity across countries. Fink et al. (2005) tackled this problem by using dynamic estimation methods and dividing economies into market ones and transition countries. They found that financial sector development exerted a positive and exogenous impact on economic growth, with productivity channels as the main growth impact. Using data from Asian countries, Mukhopadhyay et al. (2011) found mixed evidence for the finance-growth relationship, which due to supply leading theory and the possibility of financial development was perceived as not being important in some countries.

Collection of studies have attempted to focus more on industries as an additional analysis of financial development. Rajan and Zingales (1998) found that countries with larger banking systems and larger stock markets needed disproportionately faster growth of external finance. Moreover, Wurgler (2000) found that financially developed countries experienced an increase in investment in their growing industries, but received less for their declining industries, meaning investments were being allocated more efficiently. Jayaratne and Strahan (1996) exploited the variance across time, and using data from the US found that branch banking improved the quality of loans but did not increase the volume of lending. This implies that after banks are allowed to open branches, they will allocate credit more efficiently and thus experience an increase in the rate of growth of per capita income. Financial development impacted the entry of new firms in the non-financial industries in the country. Haber (2007) found that restrictions on the growth of financial intermediaries would result in an increase of differential access to capital. This would lead to higher levels of industrial concentration. Relatively speaking, small firms will experience faster growth in well-developed financial systems for technological reasons. In addition, Beck et al. (2007) demonstrated that industries comprised of small firms made up a large proportion of total manufacturing value in countries that experienced higher levels of financial development. 
Governments play the most prominent role in providing opportunities and even placing restrictions on the economy to incentivise or discourage ecomomic activities. While a range of empirical studies have shown that a well-developed financial system will benefit the economy, in needs to be asked why governments in poor countries do not create the necessary environment for large banking systems and securities markets to exist. There are three groups that have particular interest in the financial market: incumbent financiers, political entrepreneurs, and other groups of entrepreneurs. The incumbents want to protect their control of the market. Since the government holds the authority to hand out charters to banks and businesses, incumbents want to keep the charter or their own , therefore creating an invisible barrier in financial markets. This action can be justified on the basis of maintaining a stable banking system (Perotti \& Volpin, 2004). Political entrepreneurs, on the other hand, want to maintain their control in government (Bueno de Mesquita et al., 2003). In order to achieve this, they need public financing, thus incentivising them to expand the banking system. The other groups of entrepreneurs are interested in maintaining the cost of credit as low as possible to finance their business. All of these interests rarely align with each other, and the situation is also worsened by the existence of incentive mismatches regarding the property rights system.

Some empirical studies have been conducted regarding the political economy view explained above. Barth et al. (2006) found that democratic political institutions provide greater ease in obtaining bank charters as well as imposing fewer restrictions on them. Tight regulation, on the other hand, results in less bank stability and free market development. Using panel data, Bordo and Rousseau (2006) found the strong effect between political institutions and financial development resulted in proportional representation and political stability. Governments can also allow the privatisation of state-owned banks in scenarios when reform is not taking place. Eliminating the effect of asymmetric information in the market has been found to make banking systems grow over time (Kane \& Rice, 2001). Opening up the banking system to foreign banks might give larger firms greater advantages (Clarke et al., 2000). Kasekende and Sebudde (2002) found that foreign banks base their lending decisions on commercial viability, thus resulting in lower NPL than their domestic counterparts, while Cull et al. (2007) demonstrated that the problem of insider lending was mostly found in domestic banks and that they usually had higher NPL and lower rates or return. This shows that foreign banks have better internal control mechanisms than their domestic counterparts.

\subsection{Previous Studies: Islamic Banks and Economic Growth}

Many previous empirical studies have shown that the Islamic financial system represented by Islamic banks may have a positive impact on economic growth. Imam and Kpodar (2015) argue that Islamic banks are growing rapidly in the global finance field and suggest that Islamic finance is more suitable to be applied in developing countries due to its unique PLS system, which closely links Islamic banks to real activities. They further argue that Islamic banks promote economic growth and minimise economic risks such as bubbles. Therefore, they suggest that Islamic finance should be developed, especially in countries with low growth 
rates. To consider the evidence of the role of Islamic banks in economic growth, this subchapter will explore the empirical literature on this topic.

Elhachemi and Othman (2015) studied the role of Iranian Islamic bank development in terms of its activity and size in economic growth over the period 1990Q1 to 2010Q4. They applied ARDL to observe short- and long-run estimations and found that Islamic banking development had a bidirectional relationship with economic growth in the long-run. According to this study, Islamic banking development in the long-run does not Granger cause growth or financial crisis. This implies that the Islamic bank system plays an essential role in the promotion of economic growth and in minimising the negative impact of domestic and international financial crises.

In the case of Kenya, Johnson (2013) observed a positive relationship between total savings and economic growth. When there was an increase in total savins, Islamic banks may disburse more financing to the private sector or entrepreneurs to expand their business and increase economic performance. On the contrary, if total financing falls, the sources of financing also decrease, which negatively affects economic growth. Johnson suggests the introduction of policies which attract depositors to save their money in Islamic rather than conventional banks.

In addition, cross-country analysis was performed by Farahani and Dastan (2013), who considered the cases of Malaysia, Indonesia, Bahrain, UAE, Saudi Arabia, Egypt, Kuwait, Qatar and Yemen during the period 2000Q1 to 2010Q4. They employed the panel cointegration approach and found a positive and stronger impact of Islamic banks on economic growth in the long-run compared to the short-run. Cross-country analysis was also made by Wild (2015), who investigated the Southeast Asia region in the period 2000Q1 to 2012Q4 applying ARDL and 2SLS. Wild also found evidence of a positive relationship between Islamic bank development and economic growth in the long-run. In this case, the size of Islamic banking positively affected economic growth to realize financial deepening. If Islamic bank assets increase in line with economic growth, this means they may minimise the risk of global financial crisis.

Tabash and Dhankar (2014) observed a long-run relationship between Islamic banking development and economic growth in Qatar, based on data spanning the period 1990 to 2008, which included gross domestic product (GDP), total financing representing Islamic bank development, and gross fixed capital formation variables. Cointegration analysis was employed and confirmed that Islamic banks promoted economic growth in the long-run. Their results also show that total financing contributes positively to investment in the long-term.

Abduh and Omar (2015) investigated the experience of Indonesia Islamic banks in the short- and long-run. They applied the ARDL framework covering quarterly data from 2003Q1 to 2010Q2. In short, their empirical results show that there is a positive and significant relationship between the development of Islamic banks and the Indonesian economy in the short- and long-term.

Similar results were obtained by Zirek, Celebi, and Kabir Hassan (2016), who observed 14 OIC member countries from 1999-2011. Their paper employed the panel VAR method and involved other macroeconomic variables such as capital stock, inflation, unemployment, government expenditure, population growth, interest rates, offshore banking, exports, agricultural growth, and cell phones 
(representing information technology development). The Islamic banking variables employed were total deposits, total assets and total financing. Their results show that an increase in the Islamic banking variable promotes economic growth in the long-run. Islamic deposits, Islamic size and Islamic investment had significantly positive relationships. Capital stock, as well as population growth, also played an important role in economic growth, while unemployment and government expenditure had negative impacts on it. Their study also found that inflation had a positive impact on economic growth, which later proves the existence of the Philip curve. It should be noted that interest rates had no significant effect on economic growth.

In the case of Malaysia, Hachicha, Nejib and Amar (2015) studied the impact of the financing of Islamic banks on economic growth during the period 2000Q1 to 2011Q4. They applied the neoclassical production function, so capital and labour were involved in the regression as control variables. They used the Johansen and Juselius cointegration test to show the long-run relationship, while ECM was applied to detect the short-run relationship. The estimated results show that Islamic financing does not significantly affect economic growth in the long-run as the values are too small. In more detail, the coefficient value of the ratio of total Islamic banks' outstanding financing to total outstanding loans, the ratio of total financing to GDP, and the ratio of total financing to private investment were $0.187,0.148$, and 0.206 percent respectively. In addition, the average estimated coefficient of these three variables in the short-run was 0.35 . In other words, the impact of Islamic bank development in the long-run is less significant than that in the short-run. Hachicha, Nejib and Amar further analysed the low impact of Malaysia Islamic banking on economic growth in the long-run as a result of its structure not prioritising the application of the PLS-based instrument. In fact, Malaysian Islamic banks prefer to assign financing to non-participatory activities, which have a short-term impact. Therefore, they suggest that Islamic banks in Malaysia should prioritise the implementation of the PLS-based instrument, which is expected to improve economic growth and minimise income inequality. Their study is supported by Furqani and Mulyany (2009), who found that Islamic bank development did not cause economic growth. On the contrary, there is evidence that a rise in economic growth will result in Islamic bank development. Goaied and Sassi (2011) found that Islamic banks did not affect economic growth in the MENA region from 1962 to 2006. In addition, financing in the private sector reduced economic growth. A similar result was reported by Johnson (2013), who sampled Islamic banks around the world using 2SLS.

At this point, it can be concluded that Islamic banks contribute positively to economic growth when they allocate financing to business, enabling entrepreneurs to improve their business activities and thus supporting economic growth. However, some studies show that Islamic banks do not affect economic growth in the long-run, since they tend to agree on short-term financing. To the best of the authors' knowledge, none of these empirical works has specifically examined whether markup-based financing, which is economically similar to interest-based loans, will have positive impact on the economy in the very long run. This study, therefore, intends to fill this gap by examining the dynamic changes in economic 
growth in the Islamic financial system, as represented by very long-term markupbased financing.

\section{METHODOLOGY}

\subsection{Data Initialisation}

The research model involved 3000 households, 200 entrepreneurs, 200 consumption firms, and a bank. On the NetLogo platform, there will be 200 grids, where one grid connected to one entrepreneur and one firm. The initial conditions and parameters for each variable are shown in Table 1; in this research these details refers to the work of Assenza et al. (2015) and Silva (2017), with some modifications, particularly in the markup rate and profit shared with the depositors.

Table 1.

Initial Conditions and Parameters

\begin{tabular}{lc}
\hline Parameter & Initial Condition \\
\hline Number of periods & 3000 \\
Number of workers & 3000 \\
Number of firms & 200 \\
Marginal productivity of labour & 0.5 \\
Marginal productivity of capital & $1 / 3$ \\
Probability of investing & 0.25 \\
Wage & 1 \\
Liquidity of firm & 10 \\
Capital & 10 \\
Production & 5 \\
Bank equity & 3000 \\
Household wealth & 2 \\
Interest rate on credit & $6 \%$ p.a \\
Interest rate on deposits & $2 \%$ p.a \\
Profit shared with depositors & 20,10 \\
Dividend payout ratio & 0.2 \\
Marginal propensity to consume & 0.05 \\
\hline
\end{tabular}

To validate the model, this research follows the validation technique of Assenza et al. (2015) and Silva (2017) by gathering empirical data from the website of the FED of St. Louis, with time spans from 1947 quarter 1 to 2018 quarter 4. The data include GDP, consumption, investment, and unemployment. Based on availability, data on the unemployment rate cover the period 1960Q1 to 2018Q4.

\subsection{Agent-based Computational Model}

Tesfatsion (2005) defines ABMs in economics as a computational study to build an economy, modelled as evolving systems of autonomous interacting agents. The economy evolves over time as its constituent agents repeatedly interact with each other and learn from their interactions. Many studies suggest that ABMs should 
cover complex interactions amongst economic agents (Arthur, 1994, 1999; Arthur et al., 1997; Oh, 2015). The economic system is one example of a complex system (Al-suwailem, 2011). In this regard, is is created from heterogeneous interacting agents who have certain goals within an environment, a continuously developing set of institutions, arrangements and technological innovation. For example, firms change their prices depending on previous demand; therefore, the output decision of an individual is a result of an interaction.

The main advantage of ABMs is their ability to observe the dynamics of the system and hence answer the questions of how and why; for example, how equilibrium is achieved if it is achieved at all, or why a system is in disequilibrium for a long period. The ABM model also has the ability to study complex interdependent systems. Examples include the ability to model multiple markets, interactions between markets and policies, and a wide variety of heterogeneous actors and institutions (Barr, Tassier \& Ussher, 2011).

One fundamental departure of ABM modelling from more standard approaches is that events are driven solely by agent interactions once initial conditions have been specified. Therefore, rather than focusing on the equilibrium states of a system, the idea is to watch and observe if some form of equilibrium develops over time. A second key departure is the increased facility provided by agent-based tools for agents to engage in flexible social communication. This means that agents can communicate with other agents at event-driven times using messages that they themselves have adaptively scripted.

\subsection{Model Development and Sequence of Events}

This research fundamentally expands the study of Al-Suwailem (2008). Agents start to make decisions at discrete times $(t=1,2,3, \ldots \mathrm{T})$. There are three groups of agents, households $(i=1,2,3, . . H)$, firms $(f=1,2,3, \ldots, F)$ and banks $(b=1,2,3, \ldots B)$. In this case, three new sectors are introduced into the system, the business sector, i.e. firms, and the goods and labour markets.

Labour Market

1. Monthly income

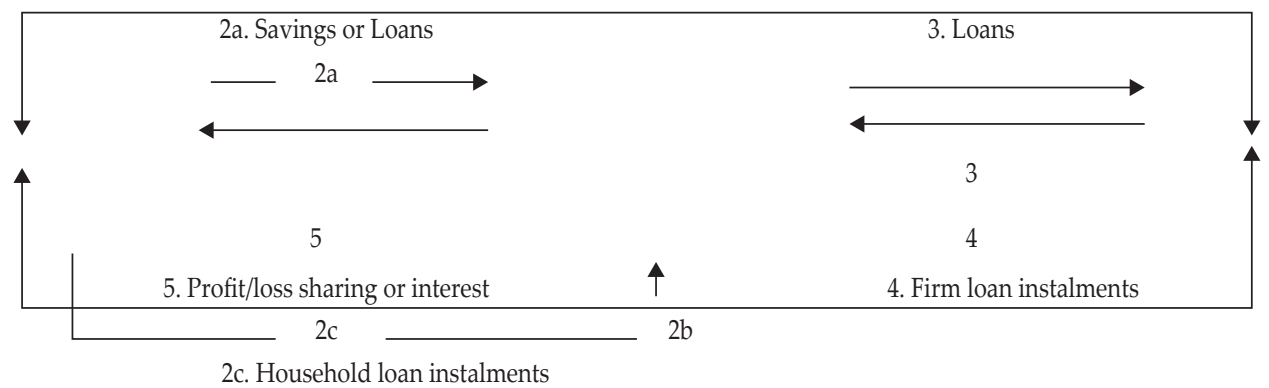

2b. Consumption expenditure

Goods Market

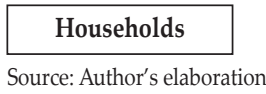

$$
\text { Bank }
$$

Firms 
The design of this research is explained in Figure 1, which shows the interconnection between households, firms and banks. Following Gaffeo et al. (2008) and Lengnick (2013), the economy is structured by the absence of market clearing mechanisms. As a consequence, the market is allowed to contain unemployment and excess household demands. In addition, the model also allows for firms to compete with each other or even go bankrupt. It is possible for firms to offer different prices depending on their internal condition and demand for the products. Therefore, the market in this research will have similar features with those in the real world. The introduction of a bank is to facilitate agents who have excess money and those who need money.

Based on Figure 1, the sequence or process overview, and scheduling in each period of $\mathrm{ABM}$ circular flow for conventional bank lending and Islamic bank financing are as follows:

1. It is assumed that each household at the beginning of period $t$ has a consumption plan. Employed households earn income paid by the firms. The labour market is supplied by the household sector. In addition, each firm has capital, investment planning, and technology.

2. Households make a decision on consumption and saving allocation based on their income. Meanwhile, firms supply a certain quantity of products at different prices and make either a profit or loss depending on its unsold products. Since one period equals 1 month, it is assumed that agents $i$ buy products for one month. If households decide to put a proportion of their income into savings, they will benefit from the interest rate paid by the banks. Savings are considered as wealth. In the case of Islamic banks, depositors will earn a share of the profit or loss. However, if the consumption of the households exceeds their income, they will request loans and need to pay monthly instalments. Available schemes of financing for consumption purposes are either interestbased in conventional banks, or markup-based in Islamic banks.

3. Firms set their targeted number of products to be produced and the number of workers to be employed, decisions which are based on past demand. Siubsequently, the entrepreneur will decide whether the firm needs financing. At this stage, the role of markup-based financing compared to that of interestbased lending on GDP will take place.

4. If a firm decide to take out loans for investment, its owner will have to make monthly instalments. Banks, therefore, play a role as a medium of saving and borrowing. In each period, each household and firm can only ask for financing from one bank. Each household and firm evaluate whether they can return their debt.

5. If the individual household and firm are able to pay the instalments, the bank will share the profit with the depositors according to the agreed percentage or ratio in the case of markup- based lending, or pay interest on the savings in the case of conventional banks. If depositors decide to keep the monthly interest rate or profit rate as an additional deposit (saving), their total wealth will increase.

6. If individual households and firms are not able to pay back their loan, they will be excluded from the system and new firm or households will be introduced into it. Therefore, the number of households and firms will be constant throughout the simulation. 
7. In the case of Islamic banks, if many borrowers are unable to pay back their loans, the depositors will be liable to loss sharing.

\section{RESULTS AND ANALYSIS}

\subsection{Results}

\subsubsection{Validation}

Validation is a process to ensure whether the simulated model links to and describes certain facts in the real world. In other words, it is not a process to compare the value of empirical and simulated data. Following Assenza et al. (2015), validation in this research was conducted by calculating the standard deviation of four main variables, GDP, consumption, investment and the unemployment rate. The closer the value of standard deviation between the simulated and empirical data, the more valid the simulated model. Both simulated and empirical data were detrended using the Hodrick-Prescott (HP) filter procedures. The results of the simulated data compared to the empirical data are shown in Table 2.

Table 2.

Standard Deviation of Empirical and Simulation Data

\begin{tabular}{llc}
\hline Variable & & Std. Deviation \\
\hline \multirow{2}{*}{ GDP } & Empirical & 1.24286 \\
& Simulation & 1.86569 \\
\hline \multirow{2}{*}{ Consumption } & Empirical & 1.02059 \\
& Simulation & 1.74212 \\
\hline \multirow{2}{*}{ Unemployment } & Empirical & 0.15704 \\
& Simulation & 0.07943 \\
\hline \multirow{2}{*}{ Investment } & Empirical & 8.40405 \\
& Simulation & 3.16182 \\
\hline
\end{tabular}

Source: Authors' calculation

Table 2 shows that standard deviation of the data generated from the simulation is relatively similar to the empirical data. In other words, the model in this research is able to examine important phenomena in the real world.

\subsubsection{Interest-based Scenario}

Figure 2 shows the levels of GDP under the interest-based system, indicating that interest on credit has a negative relation with the level of GDP; i.e., a higher interest on credit will cause lower GDP values, and vice versa. For instance, the level of GDP related to interest on credit of 6 percent (box B) is lower than that related to interest of 4 percent (box D). In the case of box $\mathrm{A}$, or when interest on credit equals 10 percent, level of GDP tends to increase significantly; however, if the length of simulation is extended to the $3000^{\text {th }}$ period, GDP will see more fluctuation and will not have the tendency to reach the maximum point. Therefore, the level of GDP inside box $\mathrm{A}$ is still lower than the levels inside boxes B, C, and D. 

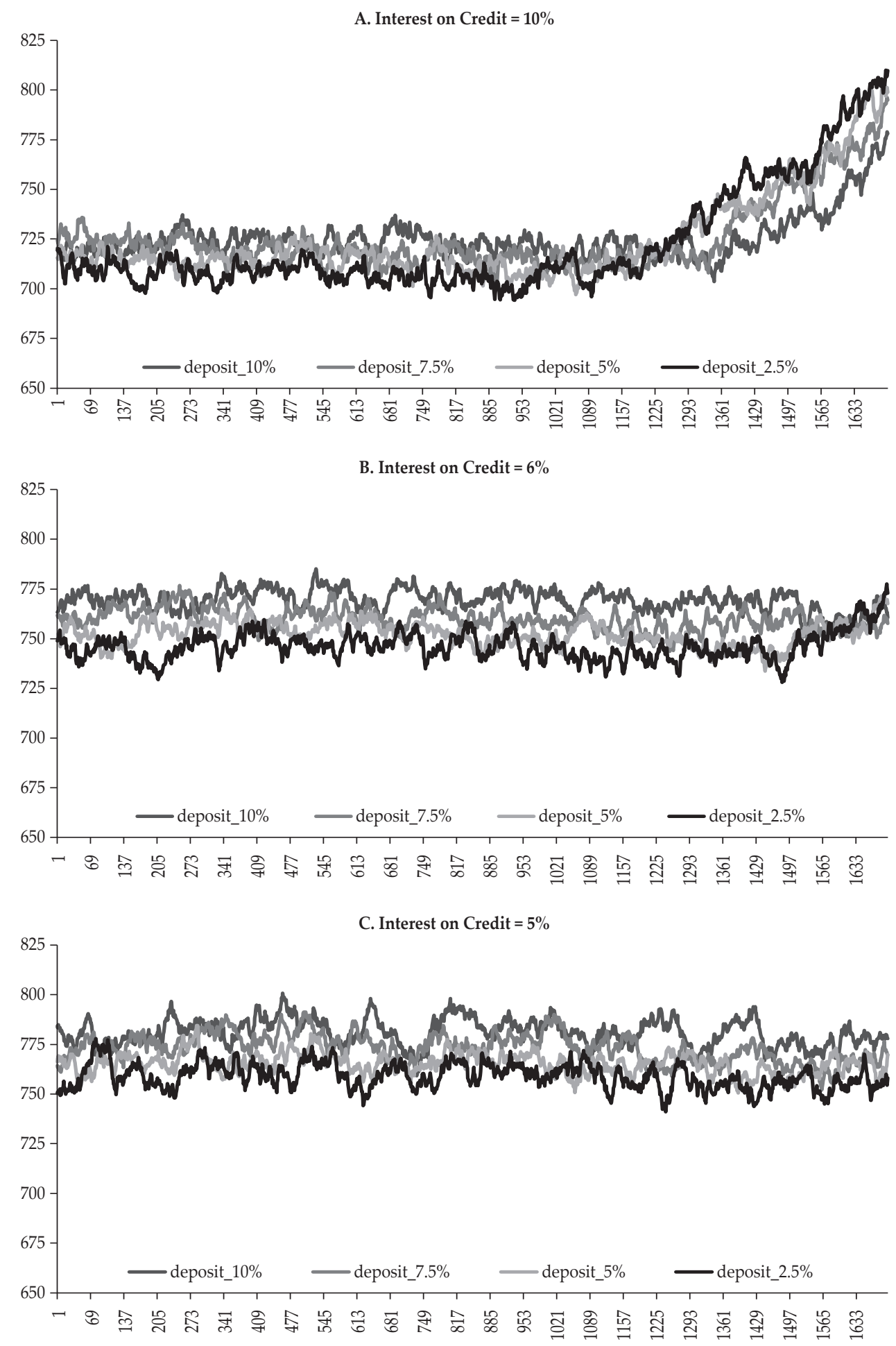

Figure 2.

GDP in the Interest-based System: All Scenarios 


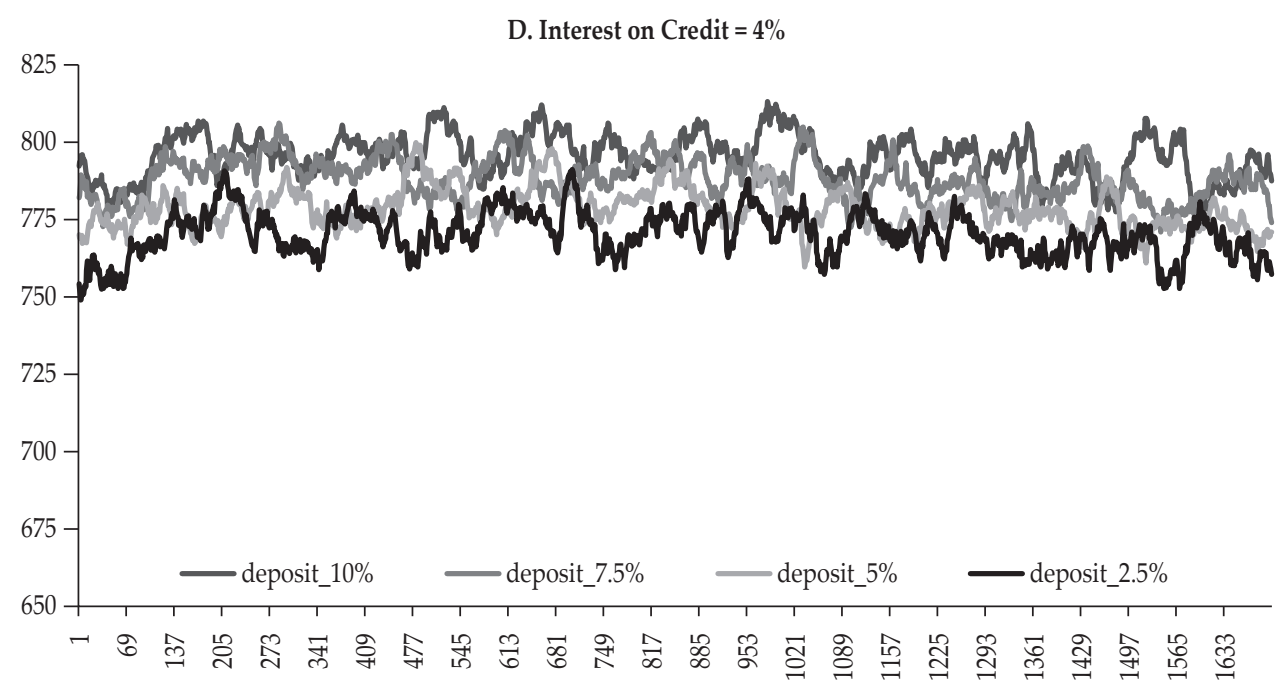

Note: The legend represents the rate of interest on deposits.

Figure 2.

GDP in the Interest-based System: All Scenarios (Continued)

Interest on deposits has a positive relationship with GDP. Figure 2 further shows that in each box A, B, C and D, the level of GDP is relatively higher when the interest on deposits is 10 percent (the blue line) and falls slightly when the interest rate is reduced to 7.5 percent (the red line), 5 percent (the green line) and 2.5 percent (the purple line). Nevertheless, interest on deposits does not have a significant impact on the level of GDP. For instance, the levels of GDP in box B are in the range of 740 points to 780 points. Therefore, it can be concluded that the rate of interest on credit has a stronger effect on the level of GDP than interest on deposits.

\subsubsection{Markup-based Scenario}

The average value of GDP in the markup-based system is higher than in the interestbased one. Unlike in the interest-based system, markup on credit positively affects GDP values. Specifically, the higher the markup rate on credit, the higher the level of GDP. For instance, Figure 3 shows that the level of GDP at a markup on credit of 10 percent (the blue line inside box $\mathrm{A}$ ) is at a higher level than at markups of 6 percent (the blue line inside box B), 5 percent (the blue line inside box C) and 4 percent (the blue line inside box D). 

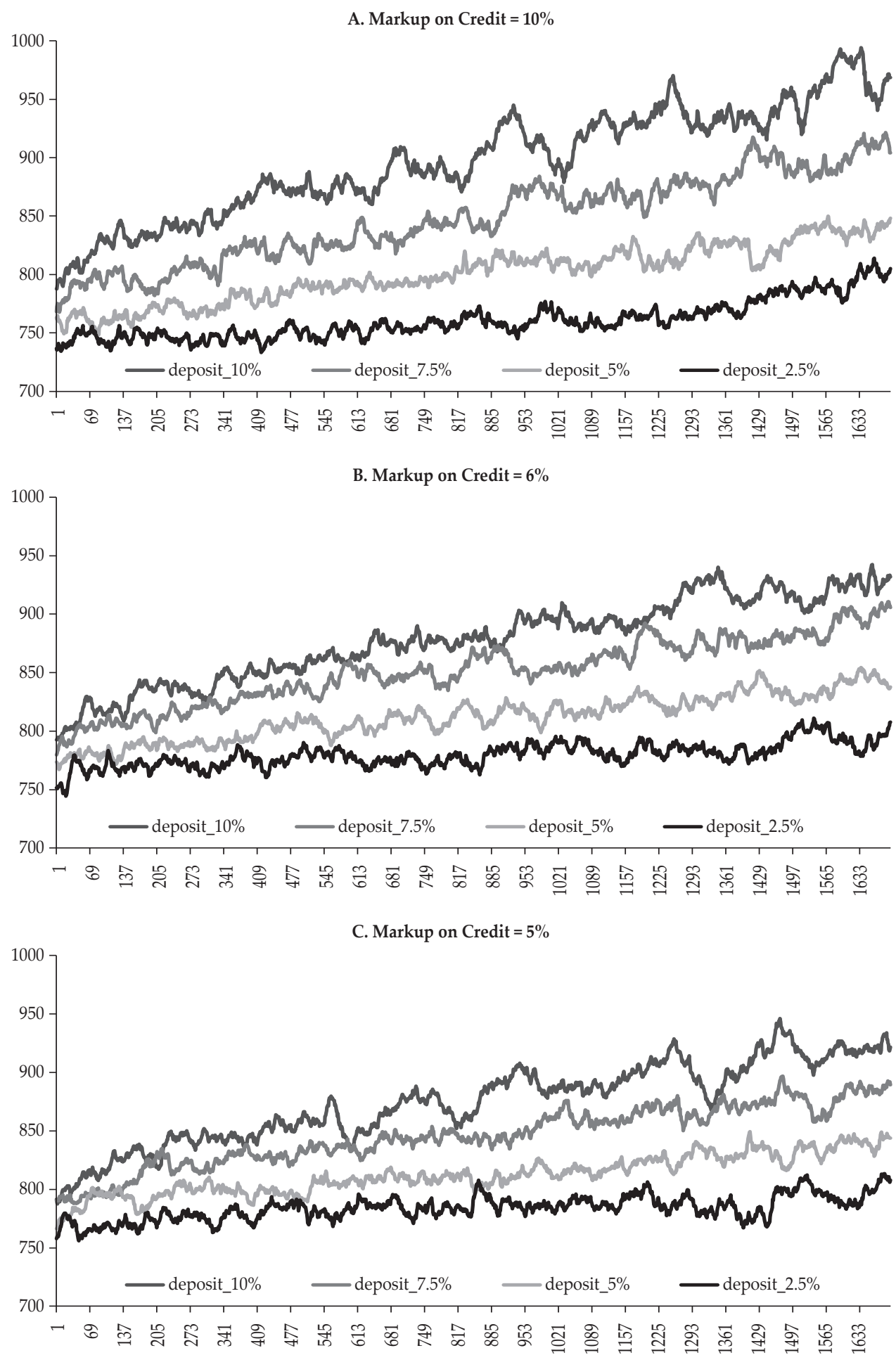

Figure 3.

GDP Markup-based System: All Scenarios 


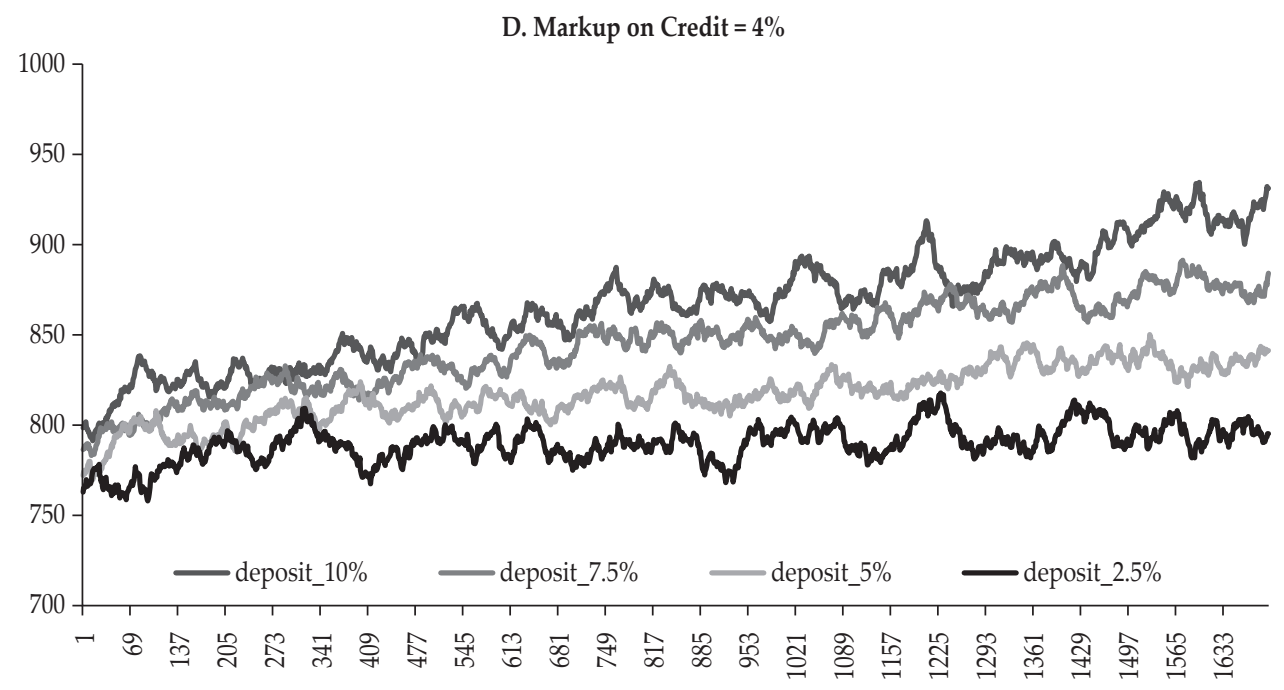

Note: The legend represents rate of profit shared on deposit

Figure 3.

GDP Markup-based System: All Scenarios (Continued)

Furthermore, Figure 3 shows that the profit shared on deposit has a positive and significant effect on GDP. In this regard, the higher the profit shared on deposit, the higher the GDP level. Boxes A, B, C and D (within Figure 3) indicate that GDP reaches its highest level when profit shared on deposit is 10 percent (the blue line), and on the other hand at its lowest point if profit shared on deposit is 2.5 percent (the purple line).

Under the markup-based system, a combination of higher markup rate on credit and higher profit shared on deposit will push GDP to a higher level. The blue lines inside boxes A, B, C and D (within Figure 3) demonstrate that the value of GDP is at its highest level when the markup on credit is 10 percent, and the profit shared on deposit is 10 percent. In this regard, it can be inferred that the similarity between interest-based lending and markup-based financing is a result of the interest rate and markup rate on credit having a negative relationship with GDP.

\subsection{Analysis}

The results of the simulation show that the economy achieves better performance under the markup-based scenario; i.e., the level of GDP is higher under markupbased financing compared to interest- based lending at almost level of interest rate on credit. In this regard, the simulation supports previous empirical works such as those of Imam and Kpodar (2015), Elhachemi and Othman (2015), Johnson (2013), and Farahani, Yasdan Gudarzi, and Dastan (2013). Tabash and Dhankar (2014), Abduh and Omar (2015), Zirek, Celebi, and Kabir Hassan (2016), Hachicha, Nejib, and Amar (2015), and Furqani and Mulyany (2009) show that Islamic bank financing promotes economic growth. The positive impact of profits shared with 
depositors on GDP proves that the Islamic financial system may create wealth for the whole of society. As wealth increases, the level of consumption will rise, which in turn stimulates future production to rise. Therefore, under the markup-based scenario, profits shared with depositors have a positive impact on GDP values. This means the Islamic financial system differs from its counterpart, even though Islamic financial institutions prefer to apply the markup-based system, which is argued to be economically similar to the interest-based approach.

In addition, the fundamental difference between the two scenarios is that no level of interest on deposits has an effect on GDP value. As previously discussed, when interest on credit is at 6 percent, the average values of GDP are similar whatever the level of interest on deposits. On the contrary, profits shared with depositors have a positive impact on GDP value. That is, the higher the profits shared with depositors, the higher the value of GDP. In other words, the simulation indirectly shows that GDP fluctuates more in the interest-based system (Figure 2) compared to the Islamic-based one (Figure 3). Dosi et al. (2012), Koesrindartoto and Novanto (2011), Takashima and Ogibayashi (2011) and Takashima, Kato, and Ogibayashi (2014) also confirm that interest rates in the economy will cause instability. This happens because in the conventional financial system, debt will grow independently, while in Islamic financing, debt cannot grow independently. In this regard, Al-Suwailem (2008) further argues that interest rates imply debt replication, since it is permitted to grow independently of real wealth, while markup-based financing is essentially only a sale . Therefore, the markup-based system will always be attached to real transactions; i.e., debt cannot grow independently of real debt. Therefore, the simulation results from the markup based-system show that there is a tendency for GDP to grow and with less fluctuation. In other words, the results of this simulation essentially confirm that the Islamic banking system represented by markup-based financing has a much better impact on economic performance rather conventional-based lending.

\section{CONCLUSION AND RECOMMENDATIONS}

\subsection{Conclusion}

This study has presented the application of an ABM to demonstrate whether there are any similarities or differences between the behaviour of GDP under the interest-based and markup-based scenarios. The simulation showed that in the interest-based system, GDP is lower (Figure 2) than that under markup-based financing (Figure 3). Consequently, the simulation supports previous empirical works that show that Islamic bank financing can promote economic growth. Based on the simulation results, this positive relationship occurs because wealth transfer is generated inside the system; i.e., the majority of households benefit from the economic gain, hence driving economic growth. In the context of the simulation, wealth transfer occurs in the economy under the markup-based system.

Conventional methodology, such as surveys or regression, are not capable of answering the research question. Islamic economics needs to move forward to reap the benefits of the advances in technology such as artificial intelligence in order to solve many research problems which have not been discussed, or to develop theories so far unconsidered. The use of ABMs is one of the alternative ways of doing this. 


\subsection{Recommendations}

Even though markup-based financing is argued to be economically similar to simple interest-based lending, the latter practice needs to be gradually abolished. In addition, the current economic system cannot apply 100 percent PLS, so markup-based financing in the Islamic banking industry should be implemented as an initial effort. The application of markup-based financing can be considered as an alternative solution to potential risk, which may emerge from the application of interest rates on loans. In addition, Islamic banks need to increase the profit shared from deposits in order to encourage customers to save their money in their institutions. Islamic banks undoubtedly compete with conventional ones, especially in value creation for its depositors and investment in long-term projects. The application of markup-based financing in this context can be used to ensure that depositors will get profit shared on deposit . Eventually, with the application of markup-based financing, it is expected that the value creation of Islamic banks will on par with conventional banks and able to minimise their risks.

\section{REFERENCES}

Abduh, M., \& Omar, M. A. (2015). Islamic banking and economic growth: The Indonesian experience. International Journal of Islamic and Middle Eastern Finance and Management, 8(2), 134-149. https://doi.org/10.1108/17538391111144515

Abdul, W. A. (2013). The role of Islamic banking on economic growth in Kenya (October, 2013) [University of Nairobi]. http://scholarship.claremont.edu/cmc_theses/642

Ahmad, A. (1984). A macro model of distribution in an Islamic economy. Journal of Research Islamic Economics, 2(1), 3-18. https://doi.org/10.1007/978-1-349-077281_7

Ahmad, A. (1987). Income determination in an Islamic economy (January 2008). Scientific Publishing Center, King Abdulaziz University.

Ahmed, A. (2010). Global financial crisis: An Islamic finance perspective. International Journal of Islamic and Middle Eastern Finance and Management, 3(4), 306-320. https://doi.org/10.1108/17538391011093252

Al-Suwailem, S. (2008). Complexity Islamic economics in a complex world: Explorations in agent-based simulation. Jeddah: King Fahad National Library Cataloging-in-Publication Data Islamic Development Bank.

Al-Suwailem, S. (2011). Behavioral complexity. Journal of Economic Surveys, 25(3), 481-506.

Anan'ich, B. (1999). State power and finance in Russia, 1802-1917: The credit office of the finance ministry and government control over credit institutions. Cambridge: Cambridge University Press.

Arthur, W. B. (1994). Inductive reasoning and bounded rationality. The American Economic Review, 84(2), 406-411. https://doi.org/10.2307/2117868

Arthur, W. B. (1999). Complexity and the economy. Science, 2(284), 107-109. https:// doi.org/10.1126/science.284.5411.107

Arthur, W. B. (2013). Complexity economics: A different framework for economic thought. Terra Economicus, 13(2).

Arthur, W. B., Durlauf, S., \& Lane, D. (1997). The Economy as an evolving complex system II (W. B. Arthur, S. Durlauf, \& D. Lane (eds.); pp. 1-14). https://doi. org/10.1016/0167-2681(91)90037-X 
Assenza, T., Delli Gatti, D., \& Grazzini, J. (2015). Emergent dynamics of a macroeconomic agent based model with capital and credit. Journal of Economic Dynamics and Control, 50, 5-28.

Azmat, S., Ghaffar, H., Azad, A. S. M. S., \& Chazi, A. (2014). Islamic banking and asset price bubbles Islamic banking and asset price bubbles. Islamic Banking and Finance Conference, 1-37.

Barr, J., Tassier, T., \& Ussher, L. (2011). Introduction to the symposium on agent-based computational economics. Eastern Economic Journal, 37(1), 1-5. Retrieved February 12, 2021 from http://www.jstor.org/stable/41239487

Barth, J. R., Caprio Jr., G., \& Levine, R. (2006). Rethinking bank regulation: Till angels govern. Cambridge: Cambridge University Press.

Beck, T., Demirguc-Kunt, A., and Levine, R. (2007). Finance, inequality, and the poor. Journal of Economic Growth, 12(1), 27-49.

Benhabib, J., \& Spiegel, M., M. (2000). The Role of financial development in growth and investment. Journal of Economic Growth, 5, 341-360.

Bordo, M. D., \& Rousseau, P. (2006). Legal-political factors and the historical evolution of the finance-growth link. NBER Working Paper, No. 12035.

Bueno de Mesquita, B., Smith, A., Silverson, R. M., \& Morrow, J. D. (2003). The Logic of political survival. Cambridge: MIT Press.

Chapra, M. (1985). Towards a just monetary system. The Islamic Foundation.

Clarke, G., Cull, R., D'Amato, L., and Molinari, A. (2000). The effect of foreign entry on Argentina's domestic banking sector.

Cogan, J. F., \& Taylor, J. B. (2010). What the government purchases multiplier actually multiplied in the 2009 stimulus package (No. w16505). National Bureau of Economic Research.

Cull, R., Haber, S., \& Imai, M. (2007). Related lending and financial development. Stanford Center for International Development Working Paper.

Davis, L. E., \& Gallman R., E. (2001). Evolving financial markets and international capital flows: Britain, the Americas, and Australia, 1865-1914. Cambridge: Cambridge University Press.

Deidda, L \& Fattouh, B. (2001). Non linearity between finance and growth. Working Paper CRENoS 200104, Centre for North South Economic Research, University of Cagliari and Sassari, Sardinia.

de Vries, J., \& der Woude, A. (1997). The first modern economy: Success, failure, and perseverance of the Dutch economy, 1500-1815. Cambridge: Cambridge University Press.

Dosi, G., Fagiolo, G., \& Roventini, A. (2008). The microfoundations of business cycles: An evolutionary, multi-agent model. Journal of Evolutionary Economics, 18(3-4), 413-432.

Goldsmith, R. (1969). Financial structure and development. New Haven: Yale University Press.

El-Masri, F. (2015). Agent-based modelling and statistical analysis of complex system with applications to financial network for failing banks. [Dissertation]. George Mason University.

Elhachemi, H. G., \& Othman, M. A. (2015a). Does the modern application of the Islamic financial system is the new recommended architecture to promote growth and prevent the outbreak and spread of future crises? International Journal of Scientific Research and Innovative Technology, 2(6), 14-26. 
Elhachemi, H. G., \& Othman, M. A. (2015b). Empirical analysis on the nexus between Islamic banking development in terms of size and activity, economic growth and financial crisis in Islamic Republic of Iran. International Journal of Scientific Research and Innovative Technology, 2(6), 27-44.

Farahani, Y. G., \& Dastan, M. (2013). Analysis of Islamic banks' financing and economic growth: A panel cointegration approach. International Journal of Islamic and Middle Eastern Finance and Management, 6(2), 156-172.

Fink, G., Haiss, P. R., \& Mantler, H., C. (2005). The Finance-growth nexus: Market economies vs. transition countries. Available at SSRN http://dx.doi.org/10.2139/ ssrn. 863424

Freedman, C., Kumhof, M., Laxton, D., Muir, D., \& Mursula, S. (2010). Global effects of fiscal stimulus during the crisis. Journal of Monetary Economics, 57(5), 506-526.

Furqani, H., \& Mulyany, R. (2009). Islamic banking and economic growth: Empirical evidence from Malaysia. Journal of Economic Cooperation and Development, 30(2), 59-74. https://doi.org/10.1017/CBO9781107415324.004

Gaffeo, E., Gatti, D. D., Desiderio, S., \& Gallegati, M. (2008). Adaptive microfoundations for emergent macroeconomics. Eastern Economic Journal, 34(4), 441-463. https://doi.org/10.1057/eej.2008.27

Goaied, M., \& Sassi, S. (2011). Financial developement, Islamic banking and economic growth: Evidence from MENA Region. International Journal of Business and Management Science, 2(4), 1-23.

Haber, S. (1991). Industrial concentration and the capital markets: A comparative study of Brazil, Mexico, and the United States, 1830-1930. The Journal of Economic History, 51(3), 559-580.

Haber, S. (1997). Financial markets and industrial development: A comparative study of government regulation, financial innovation, and industrial structure in Brazil and Mexico, 1840-1930. Pablo Alto: Stanford University Press.

Haber, S., \& Perotti, E. (2007). The political economy of finance. Mimeo: Stanford University.

Hachicha, N., \& Amar, A. Ben. (2015). Does Islamic bank financing contribute to economic growth? The Malaysian case. International Journal of Islamic and Middle Eastern Finance and Management, 8(3), 349-368.

IFSB. (2017). Islamic financial services board Islamic financial services industry stability report. http://www.ifsb.org/sec03.php.

Imam, P., \& Kpodar, K. (2015). Is Islamic banking good for growth? IMF Working Paper, No. 15(81). https://doi.org/10.5089/9781475569285.001

Jayartne, J., \& Strahan, P. (1996). The Finance-growth nexus: Evidence from bank branch deregulation. Quarterly Journal of Economics, 111(3), 639-70.

Johnson, K. (2013). The role of Islamic banking in economic growth [Claremont McKenna College]. http://scholarship.claremont.edu/cmc_theses/642

Kane, E., \& Rice, T. (2001). Bank runs and banking policies: Lessons for African policymakers. Journal of African Economies, 10, 36-71.

Kasekende, L., \& Sebudde, R. K. (2002). The Impact of foreign ownership and financial growth in Uganda;s financial sector. Bank of Uganda Mimeo, 2002.

King, R. G., \& Levine, R. (1993). Finance and growth: Schumpeter might be right. Quarterly Journal of Economics, 108(3), 717-37. 
Koesrindartoto, D. P., \& Novanto, E. (2011). Interbank lending decisions in an economic downturn : An agent-based approach. The Asian Journal of Technology Management, 4(1), 56-64.

Lengnick, M. (2013). Agent-based macroeconomics: A baseline model. Journal of Economic Behavior and Organization, 86, 102-120. https://doi.org/10.1016/j. jebo.2012.12.021

McKinnon, R. (1973). Money and capital in economic development. Washington D.C., Brookings Institution.

Mukhopadhyay, B., Pradhan, R. P., \& Feridun, M. (2011). Finance-growth nexus revisited for some Asian countries. Applied Economics Letters, 18(16), 1527-1530.

Nabi, M. S. (2012). Dual banking and financial contagion. Islamic Economic Studies, 20(2), 29-54.

Nawab, S., \& Naqvi, H. (1997). The dimension of an Islamic economic model. Islamic Economic Studies, 4(2).

North, D. C., \& Weingast, B., R. (1989). Constitutions and commitment: The evolution of institutions governing public choice in seventeenth-century England. The Journal of Economic History, 44(4), 803-832.

Oh, Y. J. (2015). Agent-based network modeling for the 2008 financial crisis and the sluggish recovery [The University of Texas at Dallas]. https://doi.org/10.1017/ CBO9781107415324.004

Perotti, E., and Volpin, P. (2004). Lobbying on entry. Tinbergen Institute Discussion Paper No. 04-088/2.

Ram, R. (1998). Financial Development and Economic Growth: Additional Evidence. The Journal of Development Studies, 35(4), 164-174.

Rajan, R., \& Zingales, L. (1998). Financial dependence growth. American Economic Review, 88(3), 559-86.

Rousseau, P. \& Sylla, R. (2003). Financial systems, economic growth, and globalization. In globalization. In historical perspective, In: M. Bordo, A. Taylor, \& J. Williamson (eds), (pp 373-413). Chicago: The University of Chicago Press.

Rosly, S. A., Afandi, M., \& Bakar, A. (2003). Performance of Islamic and mainstream banks in Malaysia. International Journal of Social Economics, 30(3), 1249-1265. https://doi.org/10.1108/03068290310500652

Siddiqi, M. N. (1983). Issues in Islamic Banking. The Islamic Foundation.

Silva, E. M., Moura, G., \& Silva, S. (2017). Macroeconomy from the bottom-up : Studying the implications of a monetary authority's behavior in a macroeconomic agent-based model with a central bank. (Issue July). Departamento de Economia e Relações Internacionais Working Paper. https://doi.org/10.13140/RG.2.2.20074.62401

Smolo, E., \& Mirakhor, A. (2010). The global financial crisis and its implications for the Islamic financial industry. International Journal of Islamic and Middle Eastern Finance and Management, 3(4), 372-385. https:/doi. org/10.1108/17538391011093306

Sugema, I., Bakhtiar, T., \& Effendi, J. (2010). Interest versus profit-loss sharing credit contract: Effciency and welfare implications. International Research Journal of Finance and Economics, 45(45), 58-67.

Tabash, M. I., \& Dhankar, R. S. (2014a). Islamic banking and economic growth - A cointegration approach. The Romanian Economic Journal, 53, 61-90. 
Tabash, M. I., \& Dhankar, R. S. (2014b). The impact of global financial crisis on the stability of Islamic banks : An empirical evidence. Journal of Islamic Banking and Finance, 2(1), 367-388.

Takashima, K, \& Ogibayashi, S. (2011). Model structure of agent-based artificial economic system responsible for reproducing fundamental economic behavior of goods market. Springer-Verlag Berlin Heidelberg.

Takashima, K., Kato, K, \& Ogibayashi, S. (2014). Analysis of the influence of firm's financing strategies for investment on GDP in an agent-based economic system. Information, 17(6b), 2538-3603.

Tesfatsion, L. (2005). Agent-based computational economics: A constructive approach to economic theory. Handbook of Computational Economics, 2, 831-880. https://doi.org/10.1016/S1574-0021(05)02016-2

Wild, H. L. J. (2015). Islamic banking presence and economic growth in Southeast Asia. International Journal of Islamic and Middle Eastern Finance and Management, $8(2), 134-149$.

Wurgler, J. (2000). Financial markets and the allocation of capital. Journal of Financial Economics, 58(1-2), 187-214. https://doi.org/10.1108/17538391111144515

Zirek, D., Celebi, F., \& Hassan, M. K. (2016). The Islamic banking and economic growth nexus: A panel VAR analysis for organization of Islamic cooperation (OIC) countries. Journal of Economic Cooperation and Development, 37(1), 69-100. 
This page is intentionally left blank 